\title{
RESPONSE OF 2 VARIETY OF Solanum melongena $L$. ON THE GRANTING OF COW'S BIO URINE
}

\author{
Ahmad Muhammad Muatho \\ Balitar Islamic University, Blitar \\ Email : Muathoahmad@gmail.com
}

\begin{abstract}
This research use Design Random (RBD) with 8 treatment combinations: 1 . Treatment A: combination of green eggplant varieties with urine dose $80 \mathrm{cc} 2$. Treatment B: combination of green eggplant variety with urine dose $120 \mathrm{cc} 3$. Treatment C: combination of eggplant varieties green with a urine dose of $160 \mathrm{cc}$ 4. Treatment D: combination of green eggplant varieties with urine dose 200 cc 5. Treatment E: combination of violet eggplant varieties with urine dose $80 \mathrm{cc} 6$. Treatment F: combination of violet eggplant varieties with urine dose $120 \mathrm{cc} 7$. Treatment G: combination of violet eggplant varieties with urine dose $160 \mathrm{cc} 8$. Treatment $\mathrm{H}$ : combination of violet eggplant varieties with urine dose $200 \mathrm{cc}$, treatment repeated 3 times so obtained 24 unit experiment, each experiment plot consist of 15 plants. Parameters observed include plant height, number of leaves, total fruit weight, fruit length and total amount of fruit per plant. Giving of cow urine has a significant effect on the parameters of plant height, number of leaves, fruit weight, fruit length, number of fruit per plant. The best treatment is a combination of violet eggplant and 160cc bio urine / plant which is no different from $200 \mathrm{cc} /$ plant.
\end{abstract}

Keywords: Eggplant, Bio Urine

Received: 2 February, 2017; Accepter: 15 March, 2017

\section{INTRODUCTION}

Eggplant is an important agricultural commodity needed in Indonesia, because eggplant has complete enough nutrition and food ingredients. The content in eggplant is potassium and vitamin A which can be useful for body. Eggplant nutrition composition per 100 gram that is water 92,70gram; ash (mineral) 0,60 gram; iron $0.60 \mathrm{mg} ; 5.70$ grams of carbohydrates; fat 0.20 gram; 0.80 gram fiber; calories 24,00 cal; phosphorus $27.00 \mathrm{mg}$; potassium $223.00 \mathrm{mg}$; calcium 30,00 mg; protein 1.10 grams; sodium 4,00 mg; vitamin B3 $0.60 \mathrm{mg}$; vitamin B2 0,05 mg; vitamin B1 $10.00 \mathrm{mg}$; vitamin A 130,00 SI; and vitamin C 5,00 mg (Budiman.2008).

Eggplant production in 2013 is 545.646ton from the area of 50,718ha, while in 2014 its production is 557,040ton from harvest area 59,7ha (Directorate General of Horticulture). Along with the increase in population followed by increased awareness of the benefits of vegetables in meeting family needs. it is necessary to increase the production of eggplant, the effort that can be done to increase the production of eggplant plants in addition to extensification, 
diversification and rehabilitation efforts also through the intensification of agriculture. One of the intensification efforts is the fertilization, stated by Prihmantoro (1999) that fertilization aims to increase the availability of nutrients needed by plants to achieve high yields and quality of crop yields. 2002).

Cow urine is a liquid manure that contains nutrients N, P, K and organic matter (Sutanto,

The results of Haerul et al (2015) showed that liquid organic fertilizer from cow urine had an effect on growth and production of tomato plant where POC concentration gave the best result and highest yield was 60 ml.tanaman

From research conducted by Hadianto Ignatius.dkk (2014), that the application of liquid organic fertilizer of cow urine with dose of 12.0001 / Ha can increase fruit length, fruit diameter, and fruit weight per eggplant. Based on the description above can be formulated the problem of research that whether the concentration of cow urine bio affect the growth and results of green eggplant varieties Milan and price 07.

The objective of the study was to determine the response of two (2) eggplant varieties (Solanum Melongena L) to the provision of cow urine bio. 2. to know the proper bio urine konsetrasi for eggplant (Solanum Melongena L).

\section{RESEARCH METHODS}

\section{Time and Place}

The research was conducted in February-May 2017 during rainy season in Rembang village, Tepas village, Kesamben sub-district, Blitar regency.

\section{Tools and Materials}

Tools used are hoes, gembor, handsprayer, meter, scales and tools that support the research process. The materials used in the research are: Eggplant seeds of green varieties milan and purple variety prince 07 , fermented beef urine, manure, pesticides, insecticides, and supporting materials in the implementation of research.

\section{Experimental Design}

The study used a randomized block design with 8 treatment combinations: 1 . Treatment A: combination of green eggplant varieties with urine dose $80 \mathrm{cc} 2$. Treatment B: combination of green eggplant varieties with urine dose $120 \mathrm{cc} 3$. Treatment $\mathrm{C}$ : combination of green eggplant varieties with a dose of $160 \mathrm{cc}$ urine 4 . Treatment D: combination of green eggplant varieties with urine dose $200 \mathrm{cc} 5$. Treatment E: combination of violet eggplant varieties with urine dose $80 \mathrm{cc} 6$. Treatment F: combination of violet eggplant varieties with urine dose 120 cc 7. Treatment G: combination of violet eggplant varieties with urine dose $160 \mathrm{cc} 8$. Treatment $\mathrm{H}$ : combination of violet eggplant varieties with urine dose $200 \mathrm{cc}$, Each treatment repeated 3 times, so there are 24 units of experiment. Each experimental unit consists of 15 plants, thus the total number is 360 plants. As the sample in the experimental unit was taken 3 plants.

\section{Variable observations}

Observable variables observed included: plant height, fruit length, total fruit weight, number of fruits per plant. 


\section{Data analysis}

The observed data were analyzed using F test at 5\% level. When the test results obtained a real difference between treatments then continued with the comparison test between treatments by using the DMRT test at the level of 5\%

\section{RESEARCH RESULT \\ Plant height}

Result of analysis of variance (ANOVA) 5\% level with Randomized Block Design (RAK) showed that combination of eggplant and urine dosage variation on eggplant height variables gave significant effect of observation age of 14 and 42 hst. hst.

Table 1. Response 2 Varieties of Eggplant (Solanum melongena 1) Against Giving Bio Urine Cattle At Various Age Observation Plant High.

\begin{tabular}{|c|c|c|c|c|}
\hline \multirow{2}{*}{ Treatment } & \multicolumn{4}{|c|}{ Plant height } \\
\hline & $14 \mathrm{hst}$ & $28 \mathrm{hst}$ & 42 hst & 56 hst \\
\hline A & $7.94 \mathrm{c}$ & $17.67 \mathrm{a}$ & $28.33 \mathrm{ab}$ & $46.55 a$ \\
\hline B & $6.78 \mathrm{abc}$ & $13.89 \mathrm{a}$ & $27.72 \mathrm{ab}$ & $48.11 \mathrm{a}$ \\
\hline $\mathrm{C}$ & $7.44 \mathrm{bc}$ & $15.45 \mathrm{a}$ & 29.06ab & $48.78 \mathrm{a}$ \\
\hline $\mathrm{D}$ & $7.11 \mathrm{abc}$ & $15.56 \mathrm{a}$ & $31.44 c$ & $52.00 \mathrm{a}$ \\
\hline $\mathrm{E}$ & $7.11 \mathrm{abc}$ & $17.56 \mathrm{a}$ & $27.33 \mathrm{ab}$ & $44.78 \mathrm{a}$ \\
\hline $\mathrm{F}$ & $5.61 \mathrm{a}$ & $16.33 \mathrm{a}$ & 26.11ab & $49.78 \mathrm{a}$ \\
\hline $\mathrm{G}$ & $5.89 \mathrm{ab}$ & $12.89 \mathrm{a}$ & $26.00 \mathrm{ab}$ & $48.78 \mathrm{a}$ \\
\hline $\mathrm{H}$ & $5.89 \mathrm{ab}$ & $12.89 \mathrm{a}$ & $23.56 \mathrm{a}$ & $46.78 \mathrm{a}$ \\
\hline
\end{tabular}

Description: The numbers followed by the same letter on the same row and column are not significantly different in the Duncan test $(\alpha=0.05)$

Result of DMRT test 5\% combination treatment of eggplant and urine dose presented in Table 1 there is a real difference in plant height aged 14 and 42 hst. Age 14 hst highest result is combination of treatment A that is $7.94 \mathrm{~cm} /$ plant. At age 42 the highest result is the combination of treatment D that is $31.44 \mathrm{~cm} /$ tanaman. Pemberian beef cattle influence on variables of plant height.It is suspected that cow urine fertilizer has high $\mathrm{N}$ so that can trigger high chilli plant in vegetative phase.

Hadianto Ignatius.dkk (2014) stated that the low availability of soil nutrients has not been sufficient for the needs of plants where organic fertilizer is generally slow in providing nutrients because it must be reformed first by microbes to be a form of compounds that can be absorbed by plants. Lamabat availability of nutrients such as that often occurs in other organic fertilizer applications cause the limited amount of nutrients that can be absorbed by plants.

This results in no difference between treatments of various doses of organic cow urine liquid fertilizer on vegetative growth. Sharif (1986) says that nitrogen $(\mathrm{N})$ is required by plants to stimulate vegetative growth of plants such as stems, roots, leaves and branches. With the availability of $\mathrm{N}$ elements that can spur enough high growth of eggplant plants.

In addition, cow urine fertilizer works to help improve the KPK (Cation Exchange Capacity) in the soil so that nutrients in plants are not easily lost and washed and plants can grow optimally, Rizal (2012) states that the benefits of liquid organic fertilizer (biourine) in addition to fertilize plants, also to maintain the stability of nutrients in the soil so that plants can absorb nutrients in the soil well, and can reduce the impact of organic waste. 


\section{Leaf Amount}

Result of analysis of variance (ANOVA) 5\% level with Randomized Block Design (RAK) showed that the combination treatment of eggplant and urine dosage varieties on eggplant variety did not significantly affect the age of 14 hst observation. However, the effect of observation was 28,42 and 56 day after plan.

Table.2 Response 2 Varieties Eggplant (Solanum melongena 1) Against Giving Bio Urine Cow At Various Age Observation Number of Leaves.

\begin{tabular}{ccccc}
\hline \multirow{2}{*}{ treatment } & \multicolumn{4}{c}{ Jumlah Daun } \\
\cline { 2 - 5 } & $14 \mathrm{hst}$ & $28 \mathrm{hst}$ & $42 \mathrm{hst}$ & $56 \mathrm{hst}$ \\
\hline $\mathrm{A}$ & $4.11 \mathrm{a}$ & $5.57 \mathrm{a}$ & $7.22 \mathrm{a}$ & $8.99 \mathrm{a}$ \\
$\mathrm{B}$ & $4.11 \mathrm{a}$ & $6.00 \mathrm{ab}$ & $7.89 \mathrm{ab}$ & $10.22 \mathrm{ab}$ \\
$\mathrm{C}$ & $4.33 \mathrm{a}$ & $6.22 \mathrm{abc}$ & $7.67 \mathrm{ab}$ & $9.11 \mathrm{a}$ \\
$\mathrm{D}$ & $4.11 \mathrm{a}$ & $6.11 \mathrm{abc}$ & $8.89 \mathrm{abc}$ & $11.78 \mathrm{ab}$ \\
$\mathrm{E}$ & $4.44 \mathrm{a}$ & $6.89 \mathrm{bc}$ & $9.67 \mathrm{bc}$ & $11.78 \mathrm{ab}$ \\
$\mathrm{F}$ & $4.44 \mathrm{a}$ & $6.22 \mathrm{abc}$ & $8.66 \mathrm{abc}$ & $11.33 \mathrm{a}$ \\
$\mathrm{G}$ & $4.33 \mathrm{a}$ & $7.00 \mathrm{c}$ & $10.55 \mathrm{c}$ & $12.22 \mathrm{~b}$ \\
$\mathrm{H}$ & $4.00 \mathrm{a}$ & $6.77 \mathrm{ab}$ & $8.44 \mathrm{abc}$ & $10.56 \mathrm{ab}$
\end{tabular}

Description: The numbers followed by the same letter on the same row and column are not significantly different in the Duncan test $(\alpha=0.05)$

Result of DMRT test 5\% combination treatment of eggplant and urine dose presented in Table 2 there is significant difference in leaf number of age 28,42 and 56 hst, Age 28 hst highest result is combination of treatment $\mathrm{G}$ that is 7.00 strands / plant. At age 42 highest result is combination of treatment $\mathrm{G}$ that is 10.55 strands / plant. While age 56 highest result is combination of treatment $\mathrm{G}$ that is 12.22 strands / plant. It is presumed that cow urine organic fertilizer is able to provide macro and micro nutrients that are needed by plants and also can improve the physical, chemical and biological properties of the soil as a planting medium that increases soil fertility

This is in accordance with the results of research Muhammad, et al (2014) in Benjamin Huruna and Ajang Maruapey (2015) reported that with the age of the eggplant, the need for nutrients especially Nitrogen $(\mathrm{N})$ can be filled completely by the soil growing so fertilizer Organic cow urine is able to increase the availability and absorption of the much needed $\mathrm{N}$ elements in the vegetative growth phase of the plant.

\section{Fruit Weight}

Result of analysis of variance (ANOVA) 5\% level with Randomized Block Design (RAK) showed that the combination treatment of eggplant and urine varieties on egg fruit fruit variables did not significantly affect harvest observation 1 . However it gives very real impact of observation of harvest 2,3. And fruit weight.

Table.3 Response 2 Varieties of Eggplant (Solanum melongena 1) Against Giving Bio Urine Cow At Various Age Observation of Fruit Weight. 


\begin{tabular}{ccccl}
\hline \multirow{2}{*}{ Treatment } & \multicolumn{4}{c}{ Bobot Buah } \\
\cline { 2 - 5 } & Panen 1 & Panen 2 & Panen 3 & \multicolumn{1}{c}{ Total } \\
\hline A & $194.33 \mathrm{a}$ & $233.67 \mathrm{a}$ & $284.00 \mathrm{a}$ & $712.00 \mathrm{ab}$ \\
B & $163.00 \mathrm{a}$ & $223.33 \mathrm{a}$ & $255.33 \mathrm{a}$ & $641.66 \mathrm{a}$ \\
C & $153.00 \mathrm{a}$ & $313.67 \mathrm{abc}$ & $235.33 \mathrm{a}$ & $702.33 \mathrm{ab}$ \\
$\mathrm{D}$ & $177.00 \mathrm{a}$ & $351.33 \mathrm{bc}$ & $311.00 \mathrm{a}$ & $839.33 \mathrm{~b}$ \\
$\mathrm{E}$ & $175.67 \mathrm{a}$ & $351.33 \mathrm{a}$ & $338.00 \mathrm{a}$ & $753.00 \mathrm{ab}$ \\
F & $137.00 \mathrm{a}$ & $239.33 \mathrm{ab}$ & $336.67 \mathrm{a}$ & $754.00 \mathrm{ab}$ \\
$\mathrm{G}$ & $177.67 \mathrm{a}$ & $371.00 \mathrm{bc}$ & $504.67 \mathrm{~b}$ & $1053.33 \mathrm{c}$ \\
H & $167.33 \mathrm{a}$ & $391.00 \mathrm{c}$ & $564.67 \mathrm{~b}$ & $1122.00 \mathrm{c}$
\end{tabular}

Description: The numbers followed by the same letter on the same row and column are not significantly different in the Duncan test $(\alpha=0.05)$

Result of DMRT test 5\% combination treatment of eggplant and urine dose presented in Table 3 there is significant difference in fruit harvesting weight 2,3 and total fruit weight. on the 2nd harvest the highest result is the combination of treatment $\mathrm{H}$ that is $391.00 \mathrm{gr} /$ plant. While the highest yield 3 yield is combination of $\mathrm{G}$ and $\mathrm{H}$ acting that is 504.67 and $564.67 \mathrm{gr} /$ plant. For total fruit weight the highest result is combination of $\mathrm{G}$ and $\mathrm{H}$ treatment that is 1053.33 and $1122.00 \mathrm{gr} /$ plant It is alleged that urine bio can increase plant growth and fruit weight.

Haerul et al (2015) stated that Growth and production of better tomato plants with the application of liquid organic fertilizer from cow urine is due to the high content of organic matter and $\mathrm{N}$ urine wherein the livestock urine contains $\mathrm{N} \pm 10 \mathrm{gl}-1$, mostly in the form of urea. Urine also contains a number of mineral elements $(\mathrm{S}, \mathrm{P}, \mathrm{K}, \mathrm{Cl}$, and $\mathrm{Na}$ ) in varying amounts depending on species and fodder, physiological and climatic conditions. It is explained that this condition is influenced by the dosage of organic fertilizer of cow urine besides containing $\mathrm{N}$ also contains $\mathrm{P}$ and $\mathrm{K}$ which is very needed in growth and productivity of eggplant so as to accelerate fertilization and fruit ripening

Subhan (1992) in Hulman Rinanto (2014) mentions that if vegetative growth is good then generative growth will also be good, as vegetative growth underpins generative growth. The higher the result of photosynthesis, the higher the photosynthate that will be produced then the result of photosynthesis in the form of carbohydrates will be accumulated in the generative part and on the accumulated carbohydrate onion produced. Biourine including organic materials so that only a small amount of nutrients needed for plant organic materials can improve the physical, chemical and biological properties of soil so that crops grown on soils that have a high organic content of the growth will be better than the plants grown on land has a low organic material.

\section{Fruit Length}

Result of analysis of variance (ANOVA) 5\% level with Randomized Block Design (RAK) showed that combination of eggplant and urine dosage variation on eggplant length did not significantly affect harvest observation 3 . However it gives a real effect of observation of 1.2 crops and total fruit length.

Table. 4 Response 2 Varieties Eggplant (Solanum melongena 1) Against Giving Bio Urine Cow At Various Age Observation Long Fruit. 


\begin{tabular}{ccccc}
\hline \multirow{2}{*}{ Perlakuan } & \multicolumn{3}{c}{ Panjang Buah } \\
\cline { 2 - 5 } & Panen 1 & Panen 2 & Panen 3 & Total \\
\hline A & $14.25 \mathrm{a}$ & $14.50 \mathrm{a}$ & $15.49 \mathrm{a}$ & $44.25 \mathrm{a}$ \\
B & $15.17 \mathrm{ab}$ & $14.39 \mathrm{a}$ & $15.33 \mathrm{a}$ & $44.89 \mathrm{ab}$ \\
C & $14.91 \mathrm{ab}$ & $15.41 \mathrm{ab}$ & $15.72 \mathrm{a}$ & $46.05 \mathrm{ab}$ \\
D & $15.67 \mathrm{ab}$ & $15.89 \mathrm{ab}$ & $15.94 \mathrm{a}$ & $47.50 \mathrm{~b}$ \\
E & $16.00 \mathrm{~b}$ & $14.78 \mathrm{a}$ & $15.72 \mathrm{a}$ & $46.50 \mathrm{ab}$ \\
F & $14.58 \mathrm{ab}$ & $15.83 \mathrm{ab}$ & $15.17 \mathrm{a}$ & $45.58 \mathrm{ab}$ \\
G & $14.67 \mathrm{ab}$ & $15.11 \mathrm{ab}$ & $14.39 \mathrm{a}$ & $44.17 \mathrm{a}$ \\
H & $15.67 \mathrm{ab}$ & $16.39 \mathrm{~b}$ & $15.95 \mathrm{a}$ & $47.61 \mathrm{~b}$
\end{tabular}

Description: The numbers followed by the same letter on the same row and column are not significantly different in the Duncan test $(\alpha=0.05)$

Result of DMRT test 5\% combination treatment of eggplant and urine dose presented in table 4 there is real difference at length of harvest observation 1,2 and total fruit length, at harvest 1 treatment $\mathrm{E}$ the highest result is $16.00 \mathrm{~cm} /$ plant. While the 2nd harvest yield of $\mathrm{H}$ highest yield is $16.39 \mathrm{~cm} /$ plant. For the total fruit length the highest result is the combination of $\mathrm{H}$ and $\mathrm{D}$ treatment that is 47.61 and $47.50 \mathrm{~cm} /$ plant The treatment of cow urine combination of $200 \mathrm{cc} /$ plant can increase the nutrient content in the soil so that the process of photosynthesis runs optimally and can be transformed to fruit formation in addition to the role of auxin found in cow urine causes increased cell division, so as to increase plant growth.

This is in line with Kiki Sanjaya's statement (2016) The higher the given dose will give higher yields such as the length of the ear. However, if it increases its supply beyond demand, it will reduce growth.

\section{Total Amount of Fruit Per Plant}

Result of analysis of variance (ANOVA) 5\% level with Randomized Block Design (RAK) showed that the combination treatment of eggplant and urine doses at fruit fruit variables gave significant effect on all harvest observation and fruit count.

Table. 5 Response 2 Varieties Eggplant (Solanum melongena 1) Against Giving Bio Urine Cow At Various Age Observation Number of Fruits.

\begin{tabular}{ccccc}
\hline \multirow{2}{*}{ Perlakuan } & \multicolumn{5}{c}{ Jumlah Buah } \\
\cline { 2 - 5 } & Panen 1 & Panen 2 & Panen 3 & Total \\
\hline A & $1.67 \mathrm{a}$ & $2.67 \mathrm{a}$ & $2.67 \mathrm{a}$ & $7.00 \mathrm{a}$ \\
B & $1.00 \mathrm{a}$ & $3.00 \mathrm{ab}$ & $3.00 \mathrm{ab}$ & $7.00 \mathrm{a}$ \\
C & $1.00 \mathrm{a}$ & $3.67 \mathrm{bc}$ & $3.33 \mathrm{abc}$ & $8.00 \mathrm{ab}$ \\
D & $1.33 \mathrm{ab}$ & $3.67 \mathrm{bc}$ & $3.67 \mathrm{bc}$ & $8.66 \mathrm{abc}$ \\
E & $1.33 \mathrm{ab}$ & $3.00 \mathrm{ab}$ & $3.00 \mathrm{a}$ & $7.33 \mathrm{a}$ \\
F & $1.33 \mathrm{ab}$ & $3.33 \mathrm{abc}$ & $3.33 \mathrm{abc}$ & $8.00 \mathrm{ab}$ \\
$\mathrm{G}$ & $1.67 \mathrm{ab}$ & $3.67 \mathrm{bc}$ & $4.00 \mathrm{c}$ & $9.66 \mathrm{c}$ \\
H & $2.00 \mathrm{~b}$ & $4.00 \mathrm{c}$ & $3.67 \mathrm{bc}$ & $9.33 \mathrm{bc}$
\end{tabular}


Description: The numbers followed by the same letter on the same row and column are not significantly different in the Duncan test $(\alpha=0.05)$

Result of DMRT test 5\% combination treatment of eggplant and urine dose presented in table 5 there is significant difference on the number of fruit of all harvest observation, Harvest 1 treatment $\mathrm{H}$ result is highest is 2.00 fruit / plant. At harvest 2 the highest result of $\mathrm{H}$ treatment is 4,0 fruit / plant. Whereas harvest 3 treatment $G$ the highest result is 4.00 fruit / planting. For the total amount of fruit the highest yield of $G$ treatment combination result is 9.66 fruit / plant It is in the guessed combination of urine treatment effect on the amount of fruit.

Sarief (2005) in Dyah Karunia Sari et al (2014) stated that each variety would require different amounts of fertilizer to support growth and produce better production. Each variety will respond to different growth and production levels.

Mappanganro N, et al. (2011) Provision of fertilizers with high concentrations to some extent can increase yields, and concentrations that exceed a certain limit will decrease yields and also plants will grow well if the nutrients provided are in a balanced amount and meet the needs of plants .

\section{CONCLUSIONS}

\section{Conclusion}

2. That the best treatment is a combination of violet eggplant and bio urine $160 \mathrm{cc} /$ plant which is not different from $200 \mathrm{cc} /$ plant.

Suggestion1. Giving of cow urine has a significant effect on the parameters of plant height, number of leaves, fruit weight, fruit length, number of fruit per plant.

Further research is needed to determine the dose of urine by combining different eggplants.

\section{REFRRENCES}

Anonim,1993.Urin-A Wased,Reneweble Natural Resource,Noragric.Norwegia.

Budiman,Eriyadi.2008. Budidaya Terung. Bandung.

Derektorat Jendral Hortikultura, Kementerian Pertanian, Statistik Produksi Hortikultura Tahun 2014.

Karunia Dyah Sari, Yaya Hasanah, Toga Simanungkalit,Respon Pertumbuhan dan Produksi Beberapa Varietas Kedelai (Glycine Max L. (MERILL) dengan Pemberian Pupuk Organik Cair, Program Studi Agroekoteknologi, Fakultas Pertanian USU, Medan 20155 Jurnal Online Agroekoteknologi . Vol.2, No.2 : 653 - 661 , Maret 2014

Rinanto Hulman, Nur Azizah dan Mudji Santosa, 2014. Pengaruh Aplikasi Kombinasi Biourin dengan Pupuk Organik dan Anorganik Terhadap Pertumbuhan Dan Hasil Tanaman Bawang Merah (Allium ascalonicum L.). Jurusan Budidaya Pertanian, Fakultas Pertanian, Universitas Brawijaya Jl. Veteran, Malang 65145 Jawa Timur, Indonesi.

Haerul, Muammar,Junyah Leli Isnaini,2015.Pertumbuhan dan Produksi Tanaman Tomat (Solanum Lycopersicum L.) Terhadap POC (Pupuk Organik Cair) Program Studi Agroteknologi Sekolah Tinggi Ilmu Pertanian YAPIN Maros, JL Dr ratu langi No 62 Maros 9511 Hal : 69-90 Sulawesi Selatan Diakses Tanggal 14 juli 2017. 
Huruna benyamin dan ajang marupey,2015.Pertumbuhan dan ProduksiTanaman Terong (Solanum melongena L) Pada Berbagai Dosis Pupuk Organik Limbah Biogas Kotoran Sapi.Mahasiswa Sarjana dan Dosen Fakultas Pertanian Universitas Muhammadiyah Sorong (UMS)Jurnal Agroforestri X Nomor 3.

Ignatius Hadianto,irianto,ahmad ridwan,2014.Respon Tanaman Terong (Solanum Melongena L.) Terhadap Pemberian Pupuk Organik Cair Urin Sapi.Fakultas Pertanian Universitas Jambi,Kampus Pinang Masak Jl. Jambi - Muara Bulian Km.15, Mendalo Darat - Jambi 36361 VOL 16 hal 31-38.

Mappanganro, N., Enny, L. S. dan Baharuddin.2011. Pertumbuhan dan Produksi Tanaman Stroberi pada berbagai Jenis danKonsentrasi Pupuk Organik Cair dan UrineSapi dengan Sistem Hidroponik Irigasi Tetes.

Rukmana, R. 1994. Bertanam Terung. Kanisisus.Yogyakarta.

Rahman Sutanto. 2002. Pertanian organik. Kasnisius.Yogyakarta.

Sanjaya Kiki,Jurnawaty Sjofjan, Nurbaiti,2016Pengaruh Pemberian Urin Sapi Dan Pupuk Npk Terhadap Komponen Produksi Tanaman Jagung Manis (Zea mays saccharata Sturt) Di Lahan Gambut,Department of Agrotechnology, Faculty of Agriculture, University of Riau, Jom Faperta Vol 3 No. 2

Syarief, E.S. 1986. Ilmu Tanah Pertanian. Pustaka Buana. Bandung.

Parnata, A. S, 2010. Untuk Meningkatkan Hasil Panen dengan Pupuk Organik. Penebar Swadaya.Jakarta. 